\title{
Manajemen Parenting untuk Remaja
}

$\overline{\text { Sugiyanto }}$

Abstrak

Teenagers are in the growing age that moves dynamically to seek and establish identity / identities. If this phase is one in the care of the risk, it would be borne by the teens themselves, families, communities and countries. The risks occurring in any ages of teen parenting among others is one of the associations having an impact on early marriage, deviant behavior and drop-out. To reduce the risks that occur in adolescents, it needs management in teen parenting, given the importance of the role of youth as the regeneration of the family and the nation are very high asset value, and the management of parenting adolescents needs to be built with a variety of strategies.

Key Words: Manajemen, Parenting, Remaja dan Geografi Tubuh.

\section{Pendahuluan}

Setiap orang tua biologis memiliki kewajiban pengasuhan terhadap anak-anaknya, karena sesuatu dan lain hal orang tua biologis dapat memindahkan pengasuhan anaknya kepada saudara terdekat dan atau institusi lain yang syah secara hukum. William Morris (1969), mendifinisikan orang tua sebagai individuindividu yang mengasuh, melindungi dan membimbing dari masa dalam kandungan, bayi hingga tahap dewasa. Dalam proses pengasuhan orang tua memberikan kasih sayang, kebutuhan materi, akses kebutuhan medis, disiplin yang bertanggungjawab, pendidikan intelektual dan moral, persiapan untuk bertanggungjawab sebagai orang dewasa dan mempertanggungjawabkan tindakan anak kepada masyarakat (Jane Brooks, 2001).

Manajemen merupakan rancang bangun dalam bentuk soft yang meminta anggota komunitas dalam rancang bangun untuk taat. Atas dasar itu dalam pengasuhan remaja perlu orang tua bersama remaja mendiskusikan membuat rancang bangun yang akan dijadikan panutan remaja dalam setiap pergaulan dan orang tua sebagai pengasuh harus selalu melakukan control pada setiap terjadi perubahan dan pertumbuhan remaja tersebut. Jika orang tua menemukan fenomena perubahan maka segera mendiskusikan kepada remaja. Dalam proses diskusi orang tua dilarang men-justice atau mengadili, tetapi orang tua atau pengasuh menunjukan fenomena dan fakta serta memberikan berbagai resiko dan kenyamanan masa depan, namum pengambil keputusan tetap diserahkan kepada remaja yang bersangkutan.

Remaja merupakan tahap pertumbuhan setelah masa kanak-kanak, fase ini sangat tepat untuk menemukenali karakter dalam rangka membentuk sikap permanen yang bergerak menuju fase dewasa., sehingga pada masa remaja dan tua mereka memiliki property personality yang permanen yang dapat membanggakan dirinya, keluarga dan masyarakat setempat, sebab tidak semua individu yang mencapai pada usia dewasa dan usia tua memiliki rasa tanggungjawab yang kokoh dan holistic dalam menghadapi perkembangan dan perubahan kehidupan.

Undang- Undang Republik Indonesia Nomer 23 Tahun 2002, menjelaskan pengertian anak adalah seseorang yang belum berumur 18 tahun, termasuk anak yang masih dalam kandungan ibunya. Menurut Undang-Undang Nomor 39 Tahun 1999 tentang Hak Asasi Manusia, anak adalah setiap manusia yang berusia dibawah 18 tahun dan belum menikah, termasuk anak yang masih dalam kandungan.

Ruh dari pengertian di atas bahwa anak adalah manusia baik yang berwujud janin dalam kandungan ibunya maupun manusia yang telah keluar dari rahim ibunya dan maksimal berusia 18 tahun. Berpijak pada pengertian tersebut maka remaja merupakan bagian dari anak. Melalui pendekatan psikologi perkembangan 
remaja dikelompokn menjadi dua yaitu remaja awal dan remaja akhir. Remaja awal adalah anak berusia 11 sampai 15 tahun dan remaja akhir adalah anak berusia di atas 15 tahun atau rentang waktu 15-18 tahun.

Menurut Sugiyanto (2011), beberapa status anak antara lain: a). amanah atau titipan dari Tuhan YME, b), penerus keturunan dari pasangan suami istri, c). status sosial bagi orang tua, d). asset bagi keluarga dan, pewaris harta, dan e). asset atau modal bagi bangsa. Atas dasar itu parenting tidak harus dilakukan orang tua biologis atau orang tua yang melahirkan, tetapi pihak lain berkewajiban dalam parenting jika orang tua biologisnya tidak mampu, seperti keluarga hingga derajat ketiga, jemaat gereja, takmir masjid, tokoh masyarakarat, dan organisasi lain yang peduli pada anak. Anak diasuh oleh siapapun anak harus mendapatkan hak-haknya, sebab hak merupakan sesuatu yang harus diterima oleh anak, jika anak tidak memperoleh haknya akan mengakibatkan berbagai masalah. Masalah tidak saja melilit anak tetapi juga orang tuanya, keluarga, masyarakat dan negara. Hak-hak anak menurut United Nations Treaty, Conventation On the Right of the Child Retrieved tahun 2009 terdiri dari: a). Hak mengetahui orang tua kandung dan hak untuk memiliki keluarga., b). Hak atas kasih sayang, penyusuan dan pengasuhan., c). Hak memperoleh identitas., d). Hak hidup dan tumbuh kembang sesuai dengan perkembangan biologis-psikologis-sosial dan spiritual (BPPS)., e). Hak untuk terpenuhinya segala kebutuhan, termasuk hak pengasuhan permanen dan kelekatan., f). Hak perlindungan hukum dan hak mendapatkan kebutuhan pokok sebagai warga Negara., g). Hak memperoleh pendidikan.

Pihak- pihak yang bertanggungjawab atas pemenuhan hak anak adalah orang tua dan anggota keluarga yang lain, negara dengan membuat kebijakan-kebijakan dan peraturan-peraturan yang membuat keluarga mampu memenuhi hak-hak anak dalam keluarga, masyarakat dengan ikut serta menciptakan lingkungan yang kondusif bagi pemenuhan hak anak, bukan menjadi pihak yang merampas hak-hak anak (Nyadi KR, 2012). Dalam Konvensi Hak Anak (KHA) mengemukakan empat prinsip yaitu: prinsip non diskriminasi, prinsip yang terbaik bagi anak, prinsip kelangsungan hidup dan perkembangan anak, prinsip penghargaan terhadap pendapat anak.

Kewajiban remaja dalam posisi sebagai anak antara lain: a). Kewajiban menghormati orang tua, wali dan guru., b). Kewajiban Mencintai keluarga, masyarakat, dan menyayangi teman., c). Kewajiban mencintai tanah air, bangsa, dan Negara., d). Kewajiban menunaikan ibadah sesuai dengan ajaran agamanya., dan e). Kewajiban melaksanakan etika dan akhlak yang mulia. (Pasal 19 UU PA 23 Tahu 2002,)

Mengingat pentingnya pengasuhan bagi anak kususnya remaja serta hal ikwal berkait dengan hak dan kewajiban remaja serta tidak dipamahaminya pengasuhan yang sebenarnya oleh para orang tua dan orang tua penganti maka artikel ini perlu dihadirkan di hadapan public "bagaimana manajemen pengasuhan yang sederhana, menyentuh dan sesuai dengan kaidah-kaidah pengasuhan yang sesungguhnya?”. Untuk menjawab pertanyaan di atas maka artikel ini akan memaparkan strategi manajemen pengasuhan remaja dalam bingkai manjemen sebagai berikut.

\section{Konsep Parenting}

Konsep Parenting mengisyaratkan bahwa anak merupakan karunia terbesar bagi keluarga, agama, bangsa dan negara, dalam kehidupan keluarga anak menjadi pewaris dan media penerus kebersambungan yang tidak bisa diputus oleh hukum. Dalam kehidupan berbangsa dan bernegara anak sebagai generasi muda yang pada waktunya akan menerima estafet kepemimpinan bangsa dan memikul serta mempertahankan keberadaan bangsa dan negera. Atas dasar itu kelahiran anak bukan kehendak anak yang bersangkutan, 
tetapi kehendak orang tua sehingga anak tidak dapat dipersalahkan dan berhak atas hak-haknya untuk dipenuhi mengingat kelak akan menjadi pewaris keluarga dan penerus bangsa.

Untuk dapat mewujudkan harapan di atas maka pengasuhan anak harus holistic dari aspek biologi, psisokologi, social, emosional, dan spiritual pada setiap perkembangnya, guna mempermudah mewujudkan harapan tersebut maka pengasuhan anak dapat dipahami dari pengertian, proses, ruang lingkup dan standar yang harus dijadikan pedoman dalam pengasuhan anak serta budaya dimana anak tersebut bertempat tinggal.

Menurut pendapat Jane Brooks, (2001) pengasuhan adalah sebuah proses tindakan dan interaksi antara orang tua dan anak. Interaksi dalam pengasuhan tergambar dalam aktivitas orang tua (ayah, ibu, pengasuh, dll) yang selalu mendampingi anak, membimbing anak, merawat anak, mengarahkan anak, memberi makan, memberi petunjuk, dan melindungi anak dalam setiap tahapan perkembangan dan pertumbuhan untuk memasuki kehidupan baru.

Jerome Kagan (1997), mendifinisikan pengasuhan atau parenting sebagai serangkaian keputusan tentang sosialisasi pada anak, yang mencakup apa yang harus dilakukan oleh orang tua/pengasuh agar anak mampu bertanggung jawab dan memberikan kontribusi sebagai anggota masyarakat termasuk juga apa yang harus dilakukan orang tua/ pengasuh ketika anak menangis, marah, berbohong, dan tidak melakukan kewajibannya dengan baik. Berns, (1997:63), pengasuhan merupakan interaksi yang berlangsung terusmenerus dan mempengaruhi bukan hanya bagi anak juga bagi orang tua. yang merujuk pada serangkaian aksi dan interaksi yang dilakukan orang tua untuk mendukung perkembangan anak.

Proses pengasuhan bukan hubungan satu arah yang mana orang tua mempengaruhi anak namun lebih dari itu, pengasuhan merupakan proses interaksi antara orang tua dan anak yang dipengaruhi oleh budaya dan kelembagaan sosial dimana anak dibesarkan, serta erat kaitannya dengan kemampuan suatu keluarga atau rumah tangga (RT) dan komunitas dalam memberikan perhatian, waktu dan dukungan untuk memenuhi kebutuhan fisik, mental, dan sosial anak-anak yang sedang dalam masa pertumbuhan serta bagi anggota keluarga lainnya (ICN 1992 dalam Engel et al. 1997). Hoghughi (2004) menyebutkan Pengasuhan mencakup beragam aktifitas yang bertujuan agar anak dapat berkembang secara optimal dan dapat bertahan hidup dengan baik. Prinsip pengasuhan menurut Hoghughi tidak menekankan pada siapa (pelaku) namun lebih menekankan pada aktifitas dari perkembangan dan pendidikan anak.

Bercermin pada difinisi pengasuhan di atas maka orang tua/pengasuh harus mampu kerjasama, mau bekerja keras dan kerja cerdas, dibutuhkan ketenangan, kejujuran, kelembutan, kepastian, kecermatan dan kedisiplinan yang tinggi. Mengingat berbagai status anak, seperti yang dijelaskan di atas, maka parenting atau pengasuhan tidak harus orang tua biologis/yang melahirkan tetapi pihak lain berkewajiban dalam parenting. Untuk mewujudkan parenting yang baik pemerintah mengeluarkan Standar Nasional Pengasuhan Anak (SNPA). Peraturan Menteri Sosial Republik Indonesia Nomor 30/HUK/2011 tentang Standar Nasional Pengasuhan Anak (SNPA) Untuk Lembaga Kesejahteraan Sosial Anak (LKSA). SNPA merupakan norma dan kreteria sebagai panduan bagi lembaga kesejahteraan social anak (LKSA) dalam pelaksanaan pengasuhan anak yang juga dapat diterapkan dalam setiap keluarga.

Hak Anak merupakan hak setiap anak yang dirinci secara spesifik dalam artikel Konvensi Hak Anak Persatuan Bangsa-Bangsa. Sebab Kovensi Hak Anak (KHA), merupakan perjanjian yang mengikat secara yuridis dan politis diantara berbagai Negara yang megatur hal-hal yang berhubungan dengan HakHak Anak. Dengan meratifikasi KHA pada tahun 1990, Pemerintah Indonesia mengakui dan melindungi hak-hak setiap anak di bawah usia 18 tahun. 
Semua difinisi dan konsep pengasuhan di atas menunjukann rambu-rambu untuk mencetak anak menjadi sosok manusia dewasa dalam kondisi yang ideal, namun demikian tidak setiap orang tua mengerti akan konsep pengasuhan. Faktor-faktor yang mempengaruhi ketidakmampuan sebagian orang tua dalam pengasuhan di atas antara lain: factor pendidikan, factor budaya, factor ekonomi, factor kesehatan, factor jaringan dan faktor fasilitas. Berpijak pada idealisme mestinya prinsip-rinsip pengasuhan yang terdiri dari a). permanensi, b). kelekatan, c). disiplin positif d). keputusan terbaik bagi anak dan e). mempertimbangkan jangka panjang bagi anak yang bersangkutan. Kelima prinsip ini terus menerus desebarluaskan dan disosialisasikan kepada keluarga, remaja dan pemuda yang akan memasuki kehidupan keluarga baru melalui berbagai media dan institusi agar prinsip-prinsip tersebut dapat terinternalisasi bagi seluruh pihak yang berkepentingan.

\section{Strategi Parenting Untuk Remaja}

Salah satu upaya pemerintah dalam rangka preventif perilaku salah terhadap remaja melalui BKKBN meluncurkan program Bina Keluarga Remaja (BKR). Program ini mengkonsep pemberdayaan keluarga kususnya perempuan (ibu) dengan model pembinaan dan partisipasi kelompok. BKR merupakan kegiatan yang dilaksanakan oleh keluarga khususnya orang tua untuk meningkatkan membimbing/pembinaan tumbuhkembang anak dan remaja secara baik dan terarah dalam rangka pembangunan sumberdaya manusia yang bertaqwa, tangguh, maju dan mandiri.

Tujuan BKR untuk meningkatkan kepedulian dan tanggungjawab orang tua agar dapat membimbing dan membina ketahanan fisik dan non fisik anak dan remaja melalui komunikasi dan interaksi yang sehat dan harmonis dalam kehidupan berumah tangga. Menurut Wiwiek MA (2005), ada dua trend besar remaja saat ini, yaitu trend positif dan trend negative. Trend positif diantaranya fisik rata-rata tinggi dan besar, lincah dan berani berterus terang, secara umum cerdas, mental secara berkelompok kuat, bergaya hedoisme dan trend negative diantaranya suka menghindari pekerjaan yang sukar, militansi rendah, perilakunya sangat cepat berubah, gejala egois dan megucilkan diri, lebih nyaman dengan mesin, menurunya rasa kasih sayang kepada sesama, matrialistik, rasa hormat kepada orang yang lebih tua semakin menurun. ketulusannya kurang, mental personal lemah (ada gejala menurunya gentleman), kurang sabar dan kurang percaya diri.

Masa remaja merupakan masa yang rentan, jika para orang tua dan pengasuh kurang jeli terhadap tumbuhkembang remaja, pergaulan dan pemilihan teman sebaya akan berdampak pada lemahnya jati diri yang mengakibatkan fatal dalam menikmati masa remaja dan suram menghadapi masa tuanya. Kondisi ini banyak terbukti bahwa penguna narkoba di Indonesia $75 \%$ para remaja dan terjadinya pernikahan dini di usia remaja. Contoh di Daerah Istimewa Yogyakarta Menurut Zainal Abidin (2012) tahun 2010 ada 253 kasus pernikahan dini, tahun 2011 ada 357 kasus pernikahan dini dan tahun 2012 ada 309 kasus pernikahan dini. Selain kasus narkoba dan pernikahan dini fenomena perkelaian antar remaja, pencurian dengan pelaku remaja serta pembunuhan dan kriminal lainnya.

Untuk meminimalisir perilaku yang negative dan mengantisipasi fenomenan negative lain para orang tua dan kader BKR harus memiliki strategi dalam pengasuhan remaja, strategi tersebut harus: a). Specific (spesifik)., b). Meansuarble (dapat diukur)., c). Action orented., d). (berorentasi tindakan)., e). Realistic (realistis)., f). Time-limited (dibatasi waktu). Menurut Seleebey D (1992), perspektif menolong berbasis kekuatan untuk remaja (klien) dengan tujuan membantu mereka harus menerapkan prinsip-prinsip dari perpespektik kekuatan sebagai berikut: a). setiap individu (remaja dan keluarganya) memiliki kekuatan), b). trauma dan kekerasan, penyakit dan perjuangan mungkin akan merugikan tetapi dapat menjadi sumber 
tantangan dan kesempatan, c). pertimbangkan aspirasi remaja, kelompok dan masyarakat secara serius, d). menolong dengan prinsip bekerjasama, e). kita nyakin bahwa lingkungan remaja penuh sumberdaya, f), semua masalah, tantangan dan peluag harus dikaji dalam kontek kepedulian dan perawatan., g). meletakan rasa percaya kepada remaja., h). kembangkan dialog dan kolaborasi., i), terapkan prinsip pemberdayaan, penyembuhan dan keutuhan., j). nyakinkan bahwa remaja pasti memiliki harapan, keuletan, ketahanan dan keanggotaan.

Menurut Probosuseno (2015), Pengasuhan remaja harus diarahkan pada hal-hal yang bersifat senang, sehat, terhormat, taqwa, mandiri dan manfaat. Mengingat sifat remaja yang masih labil seperti sabun batang yang basah sehingga licin, atas dasar itu remaja perlu memiliki teman bicara untuk berbagi perasaan yang dialami dan dimimpikan. Sumber yang sama menjelaskan ciri remaja beresiko tinggi terhadap masalah social sebagai berikut: a). sifatnya mudah kecewa, cenderung agresif dan disduktrif, b). tidak dapat menunggu yang berlebihan, c). suka mencari sensasi, cenderung mengambil resiko yang tidak tepat, d). adanya perasaan rendah diri, e). sifat mudah bosan, suka begadang, tidak suka berolahraga, cenderung makan berlebihan., f). penyimpangan perkembangan psiko seksual atau tidak mampu membentuk identifikasi seksual yang memadai, g). suka menentang norma dan prosedur legal di masyarakatdan suka protes social., h). kurang termotivasi untuk mencapai keberhasilan (sekolah), i). keterbelakangan mental, j). sudah mulai merokok pada usia dini, k). kehidupan dirinya dan keluarga kurang agamis, 1). keluarga terpecah atau over proteksi, m). perilaku meyimpang pada usia dini dan pengalaman seks yang jelek., n). perilaku anti social, o). memiliki kawan atau anggota keluarga peminum berat. Menurut Shinta P (2015) akibat pergaulan bebas remaja mengalami kehamilan atau menghamili pada usia remaja, terkena penyakit menular seksual, pendidikan terganggu dan cita-cita gagal, kematian akibat omplikasi dari kehamilan, penyakit menular seksual termasuk HIV.

Remaja adalah masa transisi dari dunia anak ke dunia dewasa, atas dasar itu para pengasuh remaja kususnya para orang tua diseyogyakan menerapkan lima manajemen prenting bagi pengasuh remaja, yaitu:

1. Manajemen sukses

Sukses adalah pilihan, para pengasuh memiliki keharusan untuk menjelaskan kepada remaja bahwa sukses itu pilihan, sebab setiap manusia lahir di dunia itu tidak ada yang salah, tetapi kelahiran ini adalah kehendak Tuhan. Dan Tuhan tidak pernah menulis dalam kitab suci-Nya "menciptakan manusia-manusia untuk hidup miskin, susah dan sengasara". Apabila kita menemui kehidupan yang susah, sengsara atau miskin itu bagian dari kesalahan manusianya. Berdasarkan penelitian dan pengalaman dibidang ilmu social jika kita temukan masyarakat miskin, sengsara, dan susah di masa tua cenderung diawali dari kehidupan remaja, seperti: kesalahan pergaulan di masa muda, motivasi untuk sukses di masa remaja tidak tertanaman, pengaruh budaya ketika usia remaja melekat dan tidak ada niatan melawan. Pada akhirnya kondisi hidup susah, sengasara dan miskin yang melekat mereka maknai nasib.

Atas dasar itu remaja harus di bangun pola pikir dan jiwanya untuk berpandangan luas dan belajar dari alam, banyak orang-orang sukses yang berangkat dari keluarga miskin, susah, tidak berpendidikan, bahkan mereka ada kekurangan dalam kesehatan dan jasmaninya. Faktor yang membuat mereka sukses adalah motivasi untuk suskses terus melekat dalam sanubari kehidupan.

2. Manajemen arsitek personality

Kebesaran Tuhan YME salah satunya ditunjukan melalui penciptaan manusia satu dengan yang lain selalu ada perbedaan, sekalipun manusia itu kembar. Para orang tua atau pengasuh harus mengajarkan bahwa setiap orang memiliki identitas dan identitas itu sebagai property personality. 
Sadarkan bahwa perbedaan yang terjadi pada individu bukan karya orang tua tetapi itu semua adalah kebesaran Tuhan YME. Sebagai contoh remaja Tutik, berusia 17 tahun dengan kondisi rambut keriting, kulit hitam, tinggi badan $145 \mathrm{~cm}$, jika menyanyi suara fales, rahang gigi malang. Kondisi fisik Tutik oleh teman, bahkan anggota keluarga dan tetangga sering dijadikan bahan ejekan atau dijadikan nama panggilan. Misalnya kalau manggil "ting kriting" atau "theng" yang artinya hitam atau "bol cebol", dll, bahkan jika menyanyi sering ditegur oleh teman "Tut jangan menyanyi suaramu cempreng".

Kondisi remaja seperti Tutik dan yang lainya orang tua dan pengasuh harus menjelaskan bahwa struktur rambut, struktur tulang, warna suara, jenis kelamin, golongan darah, dan sidik jari semuanya adalah produk Tuhan YME, setiap janin yang mau keluar dari rahim ibunya tidak dapat memesan terlebih dahulu, semua itu harus disyukuri, jadi kalau ada orang lain mengejek, remaja itu harus menjawab "jelekjelek suaraku, hitam kulitku, kriting rambutku, pendek tubuhku, dll” ini suamu produk Tuhan, kalau kalian mengejek saya berarti kalian meremahkan Tuhan dan kalian mendapat dosa.

Semua itu adalah property personality setiap individu yang harus di pahami oleh diri remaja sehingga remaja tidak perlu mengubah-ubah yang sudah permanen dari Tuhan sebab banyak individu kususnya remaja mengubah kodrat atau karya Tuhan, sehingga hasil gubahan itu hanya berlaku beberapa saat, disisi lain mengubah dapat berimbas pada penyakit, perilaku menyimpang dan di tolak lingkungan.

\section{Manajemen jodoh}

Strategi ini untuk menjadi tameng agar remaja tidak mengalami kesalahan didalam membangun keluarga di masa tua, data pernikahan dini yang diawali dengan kasus hamil pranikah dapat dicegah dengan menanamkan nilai-nilai jodoh yang ideal. Nilai-nilai yang harus sampai kepada remaja adalah menyadarkan remaja bahwa membuat kreteria jodoh lebih pentig dari pada pacaran.

Contoh Ahmad remaja usia 15 tahun, sudah mulai diajarkan tentang kreteria jodoh. Ketika saya (Ahmad) berusia 27 tahun harus menikah dengan seorang perempuan (agar tidak terjebak hubungan sejenis), beragama yang sama dengan Ahmad (untuk membangun satu ideology, agar tidak mengalami kesulitan dalam proses pernikahan dan adaptasi dengan keluarga barunya), jodoh saya wanita yang usianya lebih muda 1 sampai 3 tahun dari Ahmad, wanita ini harus bekerja (tetapi saya tidak mentarget berapa penghasilannya, sebab wanita yang bekerja akan lebih terhormat dihadapan anak, keluarga dan mertua), dll.

Dengan kreteria ini remaja akan berfikir cermat ketika didekati atau mendekat kepada lawan jenis untuk menyatakan cinta atau menerima cinta dalam rangka membangun rumah tangga baru. Para orang tua dan pengasuh ketika mengajar poit ini harus menyampaikan alternative, jika Ahmad sudah berusia 27 tahun belum mendapatkan jodohnya maka kreteria perlu ada yang diturunkan dengan berbagai alternative pertimbangan agar remaja tidak terjebak dalam keterlambatan menikah.

4. Manajemen hukum

Strategi hukum untuk menanamkan nilai-nilai kejujuran dan kedisiplin. Para orang tua dan pengasuh harus mengajarkan kepada remaja bahwa mencuri, menipu, dan perilaku menyipang lain tidak hanya diketahui oleh dirinya dan Tuhan YME. Tetapi perbuatan ini dapat dilacak oleh pihak hukum (pengadilan, kepolisian dan kedokteran) melalui sidik jari, golongan darah dan rambut pelaku penipuan, mencuri dan perilaku menyimpang lainnya dapat dibuktikan kebenarnya. Atas dasar itu tanamkan dalam situasi kepepet dan peluang kesempatan yang luas jangan sekali-kali mencuri, menipu dan perilaku menyimpang lainnya, sebab dikemudian hari akan ketahuan melalui tes kesehatan yang materialnya dari organ tubuh kita sendiri. 


\section{Manajemen penghargaan}

Jika bertemu atau berhadapan dengan remaja yang hamil diusia remaja (pra nikah) atau remaja laki-laki yang menghamili, maka pertama kali yang kita lakukan adalah ucapan selamat, sebab remaja yang bersangkutan mendapat kepercayaan oleh Tuhan menjadi wanita yang bisa hamil atau pria yang bisa menghamili, sebab tidak semua wanita dipercaya oleh Tuhan untuk dapat hamil, demikian juga tidak setiap laki-laki remaja dapat membuahi. Lalu tanyakan rencana ke depan setelah dirinya di percaya Tuhan.

Tiga misi rencana yang harus ditanamkan orang tua atau pengasuh kepada remaja adalah: a). bahwa mengugurkan kandungan sama dengan pembunuhan dilarangan oleh agama, keculai kepentingan kesehatan atas anjuran dokter ahli dan diancam pidana., b). rencana untuk janin dalam kandungan., dan c). rencana untuk diri masing-masing pelaku (remaja) dalam pemenuhan kebutuhan pendidikan, ekonomi dan social.

Larangan pengasuh dan orang tua jika mendapatkan kasus kehamilan remaja di luar nikah, marah, mencaci maki, mengusir, dan meminta mengugurkan kandungan. Atas itu tanamankan bahwa segala sesuatu yang sudah terjadi tidak boleh disesali tetapi harus dicarikan solusi.

Kasus hamil diluar nikah saja diberi penghargaan, apalagi perilaku positif remaja harus kita biasakan untuk memberi penghargaan, walaupun hanya sekedar ucapan, karena ucapan dapat dijadika motivasi pada pilihan hidup lebih baik, semangat belajar dan semangat berubah serta membangun kepercayaan diri yang akhirnya mental menjadi kuat. Contoh jika kita berjumpa remaja SMA kelas satu ketika kenaikan kelas remaja kita rengking 20 , ini harus diberi ucapan selamat "selamat nak rengking 20 dan nilainya tidak ada yang merah atau kurang" Ucapan ini akan memberi ketenangan anak dan percaya diri, tetapi jika ditunjukan sisi negative seperti “apa ini rengking 20?, memalukan dst” Remaja akan minder dan emosi sehingga dapat memicu lari pada perilaku negative sebagai camuflase atau pelampiasan atas teguran atau ejekan.

6. Manajemen geografi tubuh.

Geografi dalam artikel ini bukan dimaknai ilmu bumi, tetapi artikel ini meminjam istilah ilmu bumi untuk mencandra tata letak organ tubuh manusia, kususnya organ-organ vital yang sering menjadi sasaran nafsu bagi manusia lain maupun penyebab syahwat dan nafsu bagi diri individu.

Fakta menunjukan dalam peta tubuh manusia ada tiga titik yang menyebabkan manusia rakus, rusak perilakunya dan sakit secara fisik. Ketiga titik tersebut adalah: a). antara mulut sampai leher, orang rakus akan berbagai makanan dan minuman, segalanya dimakan. Kenikmatan dan kelezatan makan minum hanya terletak sejenggal dari mulut sampai leher, selepar leher makanan dan minuman semua jadi satu dan sudah tidak dapat dirasakan perbeadaan kenikmatan oleh setiap orang. Kelebihan makan dan minuman banyak berdampak terahadap berbagai penyakit pada organ tubuh. Disisi lain bentuk bibir dan rahang gigi menjadi dasar seseorang melebel seseorang itu cantik atau tampan. Dalam kontek jatuh cinta dan nafsu seseorang bisa muncul nafsu dan tertarik karena kondisi bibir dan rahang gigi., b). seputar dada, dada wanita adalah salah satu kekayaan yang terindah dan ini bagain aurat yang vital bagi wanita, sehingga banyak lakilaki tertarik dengan wanita karena di goda bentuk panyudara. Demikian juga para wanita sering tertarik dengan lawan jenis (pria) karena melihat dada sangat jantan, melebar berbulu dan kekar, oleh sebab itu walaupun dada pria bukan salah satu aurat yang wajib ditutup ajarkan kepada remaja pria usahakan agar selalu berpakian rapi supaya tidak merangsang orag lain atas kondisi fisik tubuh tersebut. c) bawah pusat sampai di atas lutut. Ini adalah bagi organ pria dan wanita yang wajib ditutup, sebab banyak fakta orang tertarik dan akhirnya berbuat nekat karena nafsu yang ditimbulkan daerah tersebut. Sebagai solusi dari titik rawan organ tubuh manusia di atas para orang tua dan pegasuh remaja perlu menanamkan nilai-nilai kepada 
remaja , agar remaja tidak terjerumus dalam pergaulan bebas. Ajarkan kepada remaja bahwa hanya ada tiga orang yang boleh memegang alat reproduksi, termasuk kawasan paha, mulut, gigi dan dada. Ketiga orang tersebut adalah: 1). orang tua ketika menjalin proses pengasuhan, 2). orang yang memiliki profesi kesehatan karena kepentingan pemeriksaan kesehatan seperti dokter, bidan dan perawat, 3). istri/suami ketika pasca akadnikah, selain tiga subyek tersebut yang lain tidak boleh, meraba, dan memegang karena mereka tidak berhak. Sehingga remaja harus dikuatkan dengan pesan moral bahwa peta geografi tubuh tersebut jangan sampai tersentuh dengan kepentingan yang tidak diketahui apalagi dipaksa dan disengaja. Jika nilai ini tertanaman pasti remaja tidak akan terjerumus dalam pergaulan bebas dan perilaku menyimpang lainnya.

\section{Penutup}

Sutradara dalam tumbuh kembang anak termasuk remaja adalah orang tua (pengasuh), oleh sebab pengasuh harus mampu membuat manajemen pengasuhan yang baik sebab pengasuh memiliki fungsi sebagai berikut: a). perencanaan, b). memandang masa depan., c). pengembangan., d). pengawasan, dan e). pengambil keputusan

Orang tua sebaiknya belajar menjadi orang tua dan pengasuh yang natural dengan gaya parenting yang fleksibel seperti gaya parenting demokratis, peneliti dan otoriter. Biasanya para orang tua mudah reaksi, panik dan bingung jika menghadapi masalah remaja, bahkan beberapa orang tua tidak mampu menghadapi perubahan-perubahan perilaku remaja sehingga remaja cenderung dysfunctional families. Akhirnya parenting mereka tidak hanya mempengaruhi para anggota keluarga, tetapi meluas seluruh masyarakat sebab masyarakat sendiri merupakan suatu sistem yang terdiri dari sejumlah keluarga.

Kesalahan yang sering terjadi pada orang tua adalah orang tua berapriori bahwa pengasuhan merupakan aktivitas yang bisa dilakukan secara naluriah, otomatis, dan tanpa direncanakan itu hal yang alami tidak perlu perencanaan dan tidak perlu antisipasi terhadap perubahan. Akibatnya, mereka tidak pernah secara sengaja mempelajari parenting, padahal parenting merupakan tanggung jawab utama orang tua. Atas dasar pengalaman artikel ini menawarkan kepada para orang tua dan pengasuh remaja untuk berpedoman pada lima prinsip pengasuhan dan enam manajemen yang telah dijelaskan di atas.

Bina diri remaja diarahan pada activity of daily living (ADL) atau aktivitas kegiatan harian, Bina diri mengacu pada suatu kegiatan yang bersifat pribadi tetapi berdampak pada human relationship, membangun kesadaran memperhatikan kritik, kemandirian bekerja, kebiasaan mengikuti aturan dimana saja remaja berada, dan ajarkan belajar berani mengambil keputusan,. 


\section{Bibliografi}

Anonim. 2012, Modul Latihan: Pekerjaan Sosial Berpusat Pada Anak dan Keluarga, Perlindungan Anak Dan Perencanaan Permanensi, Save the Children

Abidin, Zainal. 2012, Pernikahan Dini Di Daerah Istimewa Meningkat, Kedaulatan Rakyat, Edisi 22 Desember 2012

Jane Brook, 2011. The Proces Of Parenting, Published by Mc Graw-Hill Companies, New York. Alih bahasa Rahmat Fajar, 2011, Pustaka Pelajar, Yogyakarta.

Probosuseno, 2015. Butir-Butir Speritualitas Pendampingan Bagi Pengasuh Panti Terkait Kesehatan Reproduksi Remaja, Badan Koordinasi Kegiatan Kesejahteraan Sosial, Daerah Istimewa Yogyakarta.

Ro'fah, 2015. Pengembangan Model Pelayanan Inklusif Bagi Remaja dan Dewasa Penyandang Desabel, UIN Sunan Kalijaga Yogyakarta.

Sukinah, 2015. Upaya Optimalisasi Potensi Anak Berkebutuhan Kusus Melalui Pengembangan Bina Diri dan Gerak, Fip, UNY, Yogyakarta.

Seleebey, Dennis. 1992, The Strengths Perspective In Social Work Practice, New York:Longman.

Shinta Prawitasari, 2015, Kesehatan Reproduksi Remaja, Badan Koordinasi Kegiatan Kesejahteraan Sosial, Daerah Istimewa Yogyakarta.

Sugiyanto, 2011, Materi Pelatihan Good Parenting Untuk Pengelola LKSA, Save the Children, Yogyakarta

Sugiyanto, 2011, Motivassi Sebagai Pilar Reunivikasi Bagi Lembaga Kesejahteraan Sosial Anak dan Keluarga, Jurnal Ilmu-Ilmu Sosial Interdisiplin “Badati” edisi Volume II, No. 5, Desember 2011, Fakultas Ilmu Sosial dan Politik, Universitas Kristen Indonesia Maluku.

Wiwiek MA, 2005, Bina Keluarga Remaja Dan Pemberdayaan Perempuan (dalam Pemberdayaan Kaum Marginal), APMD Press, Yogyakarta.

William Morris, ed., The Amirican Heritage Dictionary of the English Language (Baston: Amirican Heritage Publishing and Houghton Mifflin, 1969). 